\title{
SEEDLING PRODUCTION OF Jatropha curcas L. IN SUBSTRATES FERTILIZED WITH LITHOTHAMNIUM
}

\author{
PRODUÇÃO DE MUDAS DE PINHÃO MANSO, Jatropha curcas L., EM \\ SUBSTRATOS ADUBADOS COM LITHOTHAMNIUM
}

\author{
Adão Wagner Pêgo EVANGELISTA ${ }^{1}$; Marcos Antônio VIEIRA ${ }^{2}$; José ALVES JÚNIOR ${ }^{1}$; \\ Eliana Paula Fernandes BRASIL ${ }^{1}$; Derblai CASAROLI ${ }^{1}$ \\ 1. Professor, Doutor, Universidade Federal de Goiás - UFG, Goiânia, GO, Brazil. awpego@pq.cnpq.br; 2. Engenheiro Agrônomo, \\ Mestre em Agronomia - UFG, Goiânia, GO, Brazil.
}

\begin{abstract}
Seedlings of high quality are essential for the deployment of homogeneous plants. Thus, was evaluated the formation of seedlings of Jatropha (Jatropha curcas L.) in different substrates fertilized with fertilizer-based lithothamnium. It was used substrates I) mixed of: never cultivated soil, cattle manure and sand in proportions: 3:1:1 volume/volume (v/v); II) commercial substrate Tropstrato ${ }^{\circledR}$; III) cattle manure and carbonized rice straw in proportions: 1:1 (v/v); IV) birds manure, carbonized rice straw and never cultivated soil in proportions: 1:1:4, and V) fine vermiculite. Lithothamnium fertilizer levels used were $0 \%, 5 \%$ and $10 \%(\mathrm{v} / \mathrm{v})$, respectively. The experimental design used was randomize blocks with factorial of $5 \times 3$ (five different substrates and three different lithothamnium doses) and four replication. Lithothamnium doses and substrates influenced the seedling growth of Jatropha. Seedlings fertilized with the substrates soil with mineral fertilizers (substrates 1); compost with manure and carbonized rice hulls (Substrate 3); soil with hatchery compost (Substrate 4) fertilized with a dose of $6.8 \%(\mathrm{v} / \mathrm{v})$ lithothamnium showed the best result.
\end{abstract}

KEYWORDS: Jatropha curcas L. Propagation. Plants nutrition.

\section{INTRODUCTION}

The current economic development model refers to a future scenario of depletion of fossil fuels with serious threats to the standard of the current economic growth. Despite recent discoveries of new reserves, such as the pre-salt offshore Brazil, these tend to be insufficient in the face of growth rates of demand for fuel, besides the environmental risks of this type of deepwater exploration.

This fact, coupled with the political instability in the Middle East, which concentrates $78 \%$ of world oil reserves, has encouraged researchers to seek alternative sources of fuel, which can add to mitigate environmental impacts of fossil fuel combustion associated with concepts of sustainability, reducing hunger and poverty through employment generation and distribution income.

In this context, the physic nut (Jatropha curcas L.) presents good prospects for having high potential for production of seeds with high oil yield, is a perennial oilseed, is not a food species, and therefore does not compete with food agriculture, as well allow interim planting of food species, favoring the attainment of food and energy in the same space (ARRUDA et al., 2010). According Durães et al. (2009), despite the growing interest in the world market due to the quality of your oil as the entire crop to be domesticated, there are few related to this culture scientific knowledge that will enable its cultivation on a commercial level.

With the probable demand, is necessary to spread Jatropha by vegetative means, and in this case, there is the production of seedlings from seeds in containers, justified by the low quality of seeds which has resulted large imbalance of farming. Moreover, this practice provides better control of nutritional and irrigation, maintain the integrity of the root system with a consequent increase in quality seedlings (PAULINO et al., 2011). However, to obtain seedlings with root ball, the substrate must provide physical and chemical characteristics that promote a plentiful rizomassa. Physical characteristics are influenced by the substrate textural composition and chemical composition of the nutrient composition.

The most important chemical characteristic of the substrates is $\mathrm{pH}$ (SILVEIRA et al, 2002). The $\mathrm{pH}$ of the substrates should provide values within a range considered adequate for growing plants because inappropriate values, beyond affect the availability of nutrients (CARNEIRO, 1995), are related with physiological imbalances (WILSON, 1983). For Kampf (2000), substrates with predominantly organic matter, recommendation of $\mathrm{pH}$ range is from 5.0 to 5.8 and, and to mineral soil, between 6.0 and 6.5 . 
The search for new alternative substrates is a reality due the few options on the market, especially substrates for organic cultivation which is growing especially among farmers, with differentiated and more lucrative market. The use of the fertilizer lithothamnium based on the mixture as a component substrate may be a new option. The lithothamnium is a product derived from calcareous marine algae which has in its composition $\mathrm{Ca}, \mathrm{Mg}$, $\mathrm{S}, \mathrm{Cl}, \mathrm{Mo}$ and $\mathrm{Fe}$, which favors the conditions of soil fertility and / or enhances the use of chemical fertilizer for their corrective action acidity (MELO; FURTINI NETO, 2003). The product has shown good results in the formation of seedlings of passion fruit and papaya (MENDONÇA et al, 2006;. HAFLE et al, 2009), the development of 'Cleopatra' (CROSS et al, 2008.) and also citromelo of 'swingle' (ARAÚJO et al., 2007). However, little is known about the fertilization of oilseeds with this fertilizer.

In this contest, this study aimed to evaluate the growth of seedlings of jatropha grown on substrates composed of raw materials easily obtainable associated with different fertilizer lithothamnium levels.

\section{MATERIAL AND METHODS}

The experiment was conducted in a greenhouse located in the experimental area of the College of Agronomy, Federal University of Goiás, Goiânia , GO (coordinates $16^{\circ} 35^{\prime} \mathrm{S}, 49^{\circ} 16^{\prime} \mathrm{W}$, and altitude $722 \mathrm{~m}$;). The seeds were from the experimental area of the company Caramuru Alimentos S/A, in the municipality of Itumbiara, Goiás. Five substrates were used for the sowing of seeds and seedling development: substrate 1 - mixed of: never cultivated soil, cattle manure and sand in proportions: $\quad 3: 1: 1 \quad$ volume/volume $\quad(\mathrm{v} / \mathrm{v})$, respectively, adding for each kilogram of soil, $0.9 \mathrm{~g}$ of $\mathrm{P}_{2} \mathrm{O}_{5}, 1.8 \mathrm{~g}$ of $\mathrm{K}_{2} \mathrm{O}$ and $2.0 \mathrm{~g}$ of limestone; substrate 2 - commercial substrate Tropstrato ${ }^{\circledR}$; substrate 3 - cattle manure and carbonized rice straw in proportions: 1:1 (v/v); substrate 4 - birds manure, carbonized rice straw and never cultivated soil in proportions: $1: 1: 4$; substrate 5 - fine vermiculite. Lithothamnium fertilizer levels used were $0 \%, 5 \%$ and $10 \%(\mathrm{v} / \mathrm{v})$, respectively. The chemical composition of the fertilizer based lithothamnium is shown in Table 1.

Table 1. Chemical composition of the fertilizer-based Lithothamnium.

\begin{tabular}{|c|c|c|c|}
\hline $\begin{array}{l}\text { Chemical element } \\
\text { (Macro) }\end{array}$ & $\mathrm{g} \mathrm{kg}^{-1}$ & $\begin{array}{l}\text { Chemical element } \\
\text { (Micro) }\end{array}$ & $\mathrm{mg} \mathrm{kg}^{-1}$ \\
\hline Calcium $(\mathrm{Ca})$ & 422 a 455 & Boron (B) & 8 a 20 \\
\hline Magnesium (MgO) & 38 a 53 & Manganese (Mn) & 35 a 200 \\
\hline Silicium $\left(\mathrm{SiO}_{2}\right)$ & 21 a 23 & Molybdenum (Mo) & $\leq 5$ \\
\hline Iron $\left(\mathrm{Fe}_{2} \mathrm{O}_{3}\right)$ & 2.7 a 9.7 & Zinc (Zn) & 11 a 22 \\
\hline Sulfur (S) & 2.5 a 5.2 & Cobalt (Co) & 11 a 16 \\
\hline Phosforo $\left(\mathrm{P}_{2} \mathrm{O}_{5}\right)$ & 0.4 a 1.6 & Vanadium (V) & 14 \\
\hline Potassium $\left(\mathrm{K}_{2} \mathrm{O}\right)$ & 0.2 a 0.4 & Nickel (Ni) & 15 \\
\hline Sodium $(\mathrm{Na})$ & 4.0 a 5.5 & Chrome (Cr) & 8 \\
\hline Chlorine $(\mathrm{Cl})$ & $2.0 \mathrm{a} 48$ & Copper $(\mathrm{Cu})$ & 21 \\
\hline
\end{tabular}

The total porosity, electrical conductivity and $\mathrm{pH}$ of substrates fertilized with lithothamnium is shown in Table 2.

Seedling was made in $290 \mathrm{~cm}^{3}$ conical plastic tubes, arranged in trays with 48 cells for accommodating tubes. After the seeds have been treated with the fungicide Apron ${ }^{\circledR}$ based on metalaxyl ( $1 \mathrm{ml} \mathrm{kg}^{-1}$ seed), two seeds were seedling per tube to $15 \mathrm{~mm}$ in depth, performing roughing the twenty days after seeding, leaving only one plant per core. After ten days from seeding day, we evaluated the percentage of plant emergence.

The design in randomized blocks with $5 \times 3$ factorial design (five substrates and three levels of correction based Lithothamnium $(0 \% \mathrm{v} / \mathrm{v}), 5 \%(\mathrm{v} / \mathrm{v})$ and $(10 \% \mathrm{v} / \mathrm{v})$ was used, constituting 15 treatments with four replications and 12 plants per plot, totaling 720 plants evaluated.

At 60 days after emergence (DAE), plants were submitted the following evaluations: i) plant height, considering the distance from the insertion to the apical substrate using a metal tape measure, ii ) stem diameter measured at a height of twenty millimeters above the level of the substrate, using a digital caliper, and iii) length and width of leaves to determine the leaf area (SEVERINO et al., 2007).

Subsequently the plants were separated into leaves, stem and roots and washed in running distilled water. After washing, the samples were packed in paper bags and brought to a drying oven with forced air circulation at a temperature of $65^{\circ} \mathrm{C}$ for $72 \mathrm{~h}$ until constant weight was determined that 
the dry weight of root, leaf and stem, an electronic scale.

Table 2. Total porosity (Pt), electrical conductivity (CE) e $\mathrm{pH}$ dos substrates fertilized with lithothamnium.

\begin{tabular}{ccccc}
\hline Substrates $^{*}$ & Levels $(\%)$ & $\mathrm{Pt}(\%)$ & $\mathrm{CE}\left(\mathrm{d} S \mathrm{~m}^{-1}\right)$ & $\mathrm{pH}$ \\
\hline 1 & 0 & 55 & 2.1 & 6.7 \\
1 & 5 & 57 & 1.7 & 7.3 \\
1 & 10 & 59 & 1.0 & 7.6 \\
2 & 0 & 60 & 0.2 & 6.0 \\
2 & 5 & 63 & 0.8 & 7.5 \\
2 & 10 & 63 & 0.7 & 7.8 \\
3 & 0 & 61 & 0.4 & 8.2 \\
3 & 5 & 63 & 1.0 & 8.3 \\
3 & 10 & 66 & 0.5 & 8.7 \\
4 & 0 & 74 & 0.2 & 8.5 \\
4 & 5 & 77 & 0.3 & 8.6 \\
4 & 10 & 79 & 0.4 & 6.4 \\
5 & 0 & 69 & 0.1 & 6.5 \\
5 & 5 & 70 & 0.1 & 6.6 \\
5 & 10 & 71 & 0.1 & \\
\hline
\end{tabular}

*substrate 1: mixed of: never cultivated soil, cattle manure and sand; substrate 2: Tropstrato ®; substrate 3: cattle manure and straw carbonized rice; substrate 4: birds manure, carbonized rice straw and never cultivated soil, carbonized rice straw and never cultivated soil; substrate 5: vermiculite.

The results were subjected to analysis of variance in which the qualitative treatments had their averages compared by Tukey test at 5\% probability of error and the quantitative analysis was performed regression treatments.

\section{RESULTS AND DISCUSSION}

\section{Percentage of emergence and plant growth}

Substrates and fertilization lithothamnium influenced the growth of plants of Jatropha. For percentage plant emergence, stem diameter and leaf area, there were significant interaction between fertilization rates and substrate effect, while for the height of plants to levels of lithothamnium influenced separately.

The incorporation of lithothamnium to substrates composed of soil never cultivated, cattle manure and sand (substrate 1) and cattle manure and carbonized rice straw (substrate 3), increased the percentage of plant emergence. The effect was linear, with greater response when levels of fertilizer was applied. This may probably be due to high concentration of organic matter present in these substrates associated with the incorporation of increasing doses of fertilizer can be increased microporosity of the substrates with a consequent increase in the water retention capacity for the substrates. It can be seen in Table 2, there was improvement in the physical properties of the substrate due probably reducing the pore size and arrangement of particles, with the application of levels of lithothamnium. A good porosity allows movement of water and air to the substrate, promoting germination.

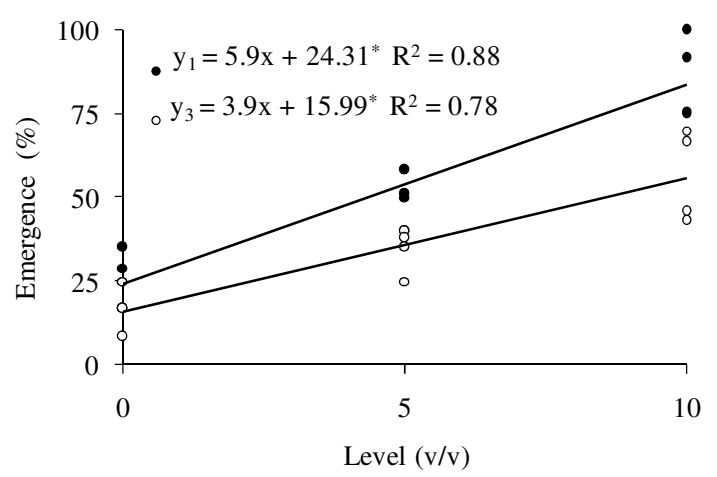

Figure 1. Emergence percentage of jatropha plants grown in substrates 1 and 3 , depending on the lithothamnium level applied. *: Significant $(\mathrm{p}<0.05)$. 


\section{Plants Height}

The composition of the substrate influenced the growth of plants of jatropha in height. The substrate consists of composted for birds manure, carbonized rice straw and never cultivated soil ( Substrate 4 ), showed the best results, while plants grown with vermiculite ( substrate 5 ) were those who achieved the lowest height (Figure 2a). The ideal characteristics of a substrate depends on the requirements of the cultivated species, so it is difficult to find a material which alone satisfies all the nutritional and physical conditions for proper growth of plants (LIMA et al , 2006; . LIMA et al, 2009). Furthermore, there are various materials which cause problems such as release of plants chemical allele and high $\mathrm{C} / \mathrm{N}$ ratio substances,

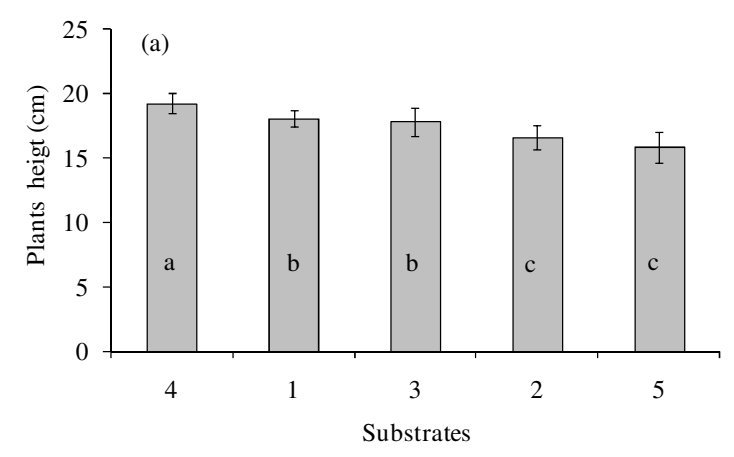

making it preferable to use mixtures of two or more organic materials to form a good substrate. A likely explanation for the positive effect of the substrate 4 can be associated with the high proportion of organic compounds in the compost bird manure, which may be promoted improvement in the fertility of the substrate. Furthermore, it is possible that the high particle size of the carbonized rice husk has improved some physical characteristics of the substrate, such as aeration and drainage. For plants of jatropha, Paulino et al . (2011) found that the physical properties of the substrate are essential for the full development of the plants as the cultivation of plants in containers limits the development of the root system, directly influencing the absorption of water and nutrients .

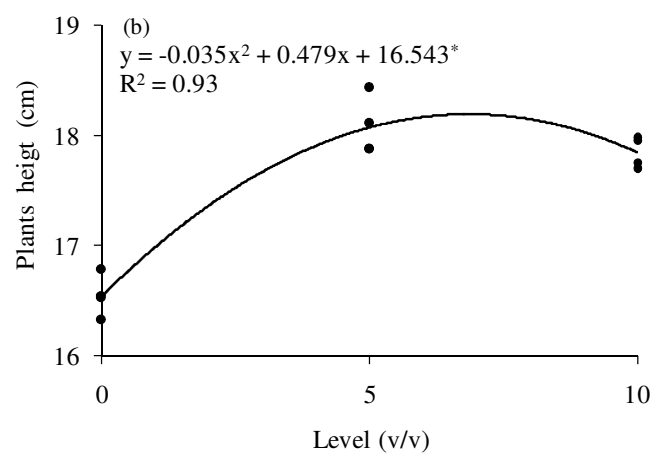

Figure 2. Plants height of jatropha (a) in relation to substrates and (b) depending on the level of lithothamnium applied. *: Significant $(\mathrm{p}<0.05)$.

The fertilization with lithothamnium to substrates also provided beneficial for plants height, which followed the quadratic model (Figure 2b), with an increase to the application of lithothamnium level of $6.84 \%(\mathrm{v} / \mathrm{v})($ height $=18$ end $18 \mathrm{~cm})$, from which there was a decrease, possibly due to increased $\mathrm{pH}$ of the substrates with the addition of calcium present in lithothamnium (Table 2), forming insoluble phosphates (RAIJ, 1991), and reduce the availability of micronutrients such as manganese, iron, zinc, copper and boron (LOPES, 1999).

The height and stem diameter of plants are important indicators of survivability of the plants, since they reflect root development and ability to adapt to adverse field conditions (ARRUDA et al., 2010). According to Carvalho et al. (2011) Jatropha plants are transplanted in the field of $150 \mathrm{~mm}$, when passing from herbaceous to woody stage. Horshultz et al. (2012) and Camargo et al. (2010) found that jatropha plants produced in polyethylene bags with organic substrate when transplanted with $170 \mathrm{~mm}$ height showed good development in the field.
Considering the length of stay in the nursery 60 days, the plants with the substrates 1,3 and 4 , showing height compatible for a good performance in field.

\section{Diameter of stem}

To stem diameter was verified effect of levels of fertilizers when applied on the substrate composed of cattle manure and carbonized rice straw (substrate 3). The stem diameter of plants receiving the application lithothamnium in linear behavior, with the level of $10 \%(\mathrm{v} / \mathrm{v})$ provided the highest stem diameter $(10.63 \mathrm{~mm})$.

According to Daniel et al. (1997) the characteristic stem diameter is recommended for inferring the survivability of plants in the field and also as a parameter to assist in determining the levels of fertilizers to be applied in the production of seedlings. Another important aspect is the greater mechanical strength afforded by this feature, along with a larger volume of sap conducting vessels, ensuring greater flow inside the plant. The largest stem diameter for this treatment can be explained by 
the greater supply of nutrients to plants, due to the mineralization of organic matter in the cattle manure, which constantly supplies the soil base. Increasing the $\mathrm{pH}$ of the substrate brought about by the addition of lithothamnium (Table 2), may have influenced microbial activity, favoring the release of nitrogen and basic cations, the decomposition and mineralization of organic matter.

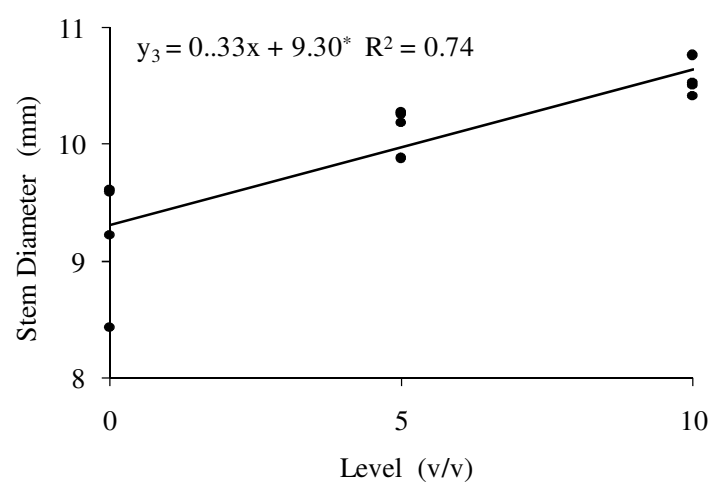

Figure 3. Stem diameter of plants of jatropha in function of level of lithothamnium applied on the substrate 3. ${ }^{*}$ : Significant $(\mathrm{p}<0.05)$.

\section{Leaf Area}

The addition of fertilizer-based lithothamnium the substrate composed of cattle manure and carbonized rice straw (substrate 3) also contributed to the increase in leaf area of seedlings, such as quadratic response (Figure 10), the level being $6.82 \%(\mathrm{v} / \mathrm{v})$ lithothamnium, which provided greater seedling leaf area $\left(234.63 \mathrm{~cm}^{2}\right)$ (Figure 4).

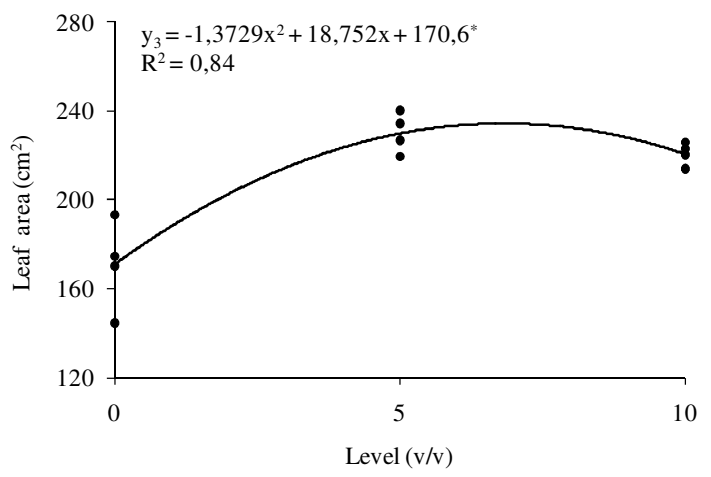

Figure 4. Leaf area of seedlings of jatropha in function of the applied levels of Lithothamnium in substrates 3.

*: Significant $(\mathrm{p}<0.05)$.

We emphasize that the leaf area of plants is directly related to the photosynthetic capacity and light interception and also interferes with ground cover, in competition with other plants and various other characteristics (SEVERINO et al., 2004). In this work, the average number of leaves of seedlings with the substrate 3 was 4.25 , then this substrate, fertilized with the level $6.82(\mathrm{v} / \mathrm{v})$ lithothamnium contributed to the production of quality seedlings, as this growth characteristic of plant.

\section{Dry biomass}

The analysis of variance indicated that there was interaction between the levels of lithothamnium and substrates only for dry biomass while leaf dry biomass of stem and roots was affected by the substrates.

The increase in the level of lithothamnium when applied on the substrate composed of composted bird manure, carbonized rice straw and never cultivated soil (substrate 4) (Figure 5), promoted the reduction in biomass of the leaves of the seedlings. This depressive effect may be due to nitrogen deficiency observed by visual symptoms in seedlings grown with this substrate and can be explained by the increased $\mathrm{pH}$ of the substrate by the addition of calcium present in composting bird manure and lithothamnium, with a consequent 
increase the rate of mineralization of organic matter, favoring the release and loss of the nitrogen contained in the system with increasing level of fertilizer applied. We emphasize that due to this fact, we observed the abscission of older leaves produced with this substrate.

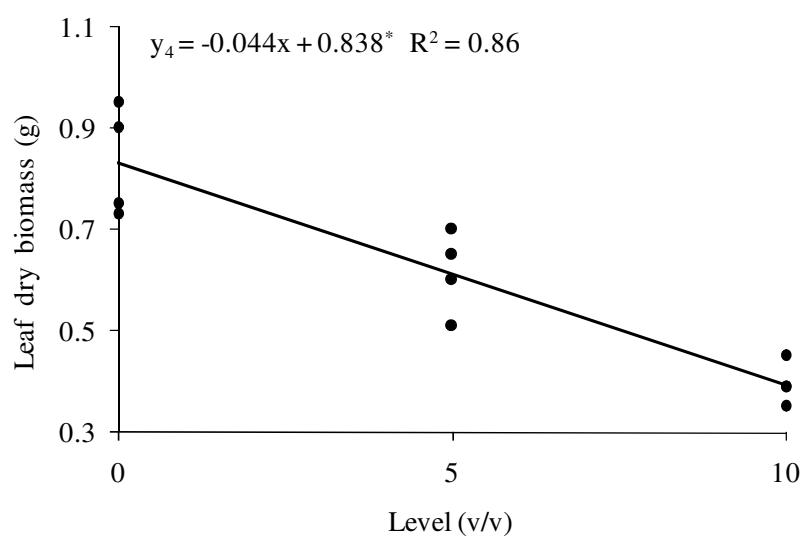

Figure 5. Leaf dry biomass of seedlings of jatropha in function of level of lithothamnium applied on the substrate $4 .^{*}:$ Significant $(\mathrm{p}<0.05)$.

The maximum accumulation of biomass of the stem was $3.96 \mathrm{~g}$, recorded in seedlings with the substrate composted bird manure, carbonized rice straw and never cultivated soil (Substrate 4) (Figure $6 a)$. For root dry biomass verified the superiority of substrates cattle manure and carbonized rice straw substrate (3), composting of bird manure, carbonized rice straw and never cultivated soil (Substrate 4) and consists of never cultivated soil, cattle manure and sand substrate (1), which produced seedlings with root dry biomass with 1.0 $\mathrm{g}, 0.92 \mathrm{~g}$ and $0.75 \mathrm{~g}$, respectively (Figure 6a). The commercial substrate (substrate 2) with the compound by vermiculite (substrate 5) were the treatments who show the worst result in root dry biomass $(0.33 \mathrm{~g}$ and $0.25 \mathrm{~g})$.

The malformation of the root system of perennial plants may not cause plant death, but

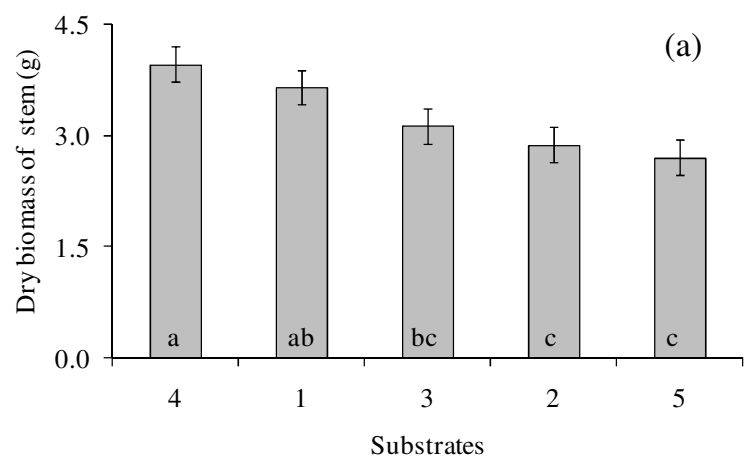

remain harming their productivity throughout the production cycle, which may represent decades producing below their agronomic potential (SEVERINO, 2007). In the trimming step of the experiment it was observed that the root system of the plants produced from the substrate 3 had no fertilization deformation roots, which reduced this symptom by adding lithothamnium did not occur and the substrate 5 with pure vermiculite demonstrating the anti-stress effect calcium performed by the maintenance of membrane integrity of plant tissues. According Epstein e Bloom (2004), sensitive to salts, plants are more tolerant to salts when grown in high calcium concentrations.

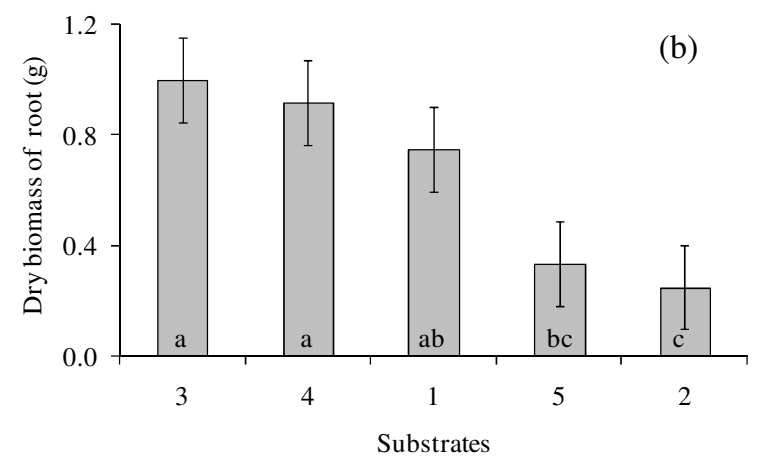

Figure 6. Dry biomass, (a) stem (b) root, jatropha seedlings in relation to substrates. 


\section{CONCLUSION}

For the formation of seedlings of jatropha is recommended to use any of the following substrates: i) never cultivated soil, cattle manure and
EVANGELISTA, A. W. P. et al.

sand ii) cattle manure and straw carbonized rice iii) composting of bird manure, carbonized rice straw and never cultivated soil; and fertilized with an average level of $6.8 \%(\mathrm{v} / \mathrm{v})$ of lithothamnium.

RESUMO: A qualidade da muda é fundamental para implantação de lavouras homogêneas. Desta forma, avaliou-se o crescimento de mudas de pinhão manso (Jatropha curcas L.,), em diferentes substratos adubados com fertilizante à base de lithothamnium. Foram utilizados os substratos: I) terra de barranco, esterco bovino curtido e areia nas proporções 3:1:1 volume/volume (v/v), respectivamente; II) substrato comercial denominado Tropstrato ${ }^{\circledR}$; III) esterco de curral e palha de arroz carbonizada na proporção de $1: 1(\mathrm{v} / \mathrm{v})$; IV) compostagem de incubatório de aves, palha de arroz carbonizada e terra de barranco na proporção $1: 1: 4$; e V) vermiculita pura de granulação fina. As doses do fertilizante à base de lithothamnium utilizadas foram: $0 \%, 5 \%$ e $10 \%(\mathrm{v} / \mathrm{v})$, respectivamente. $\mathrm{O}$ desenho experimental foi $\mathrm{o}$ delineamento em blocos casualisados, em esquema bifatorial $5 \times 3$ (cinco substratos e três doses de fertilizante) e quatro repetições. Cada unidade experimental (parcela) foi composta por doze mudas. As doses de lithothamnium e os substratos influenciaram o crescimento de mudas de pinhão manso. As mudas produzidas com os substratos composto por terra de barranco, esterco bovino curtido e areia; esterco de curral e palha de arroz carbonizada e Compostagem de incubatório de aves, palha de arroz carbonizada e terra de barranco adubadas com a dose média de 6,8\% (v/v) de lithothamnium, apresentaram o melhor resultado.

PALAVRAS-CHAVE: Jatropha curcas L. Propagação. Nutrição de plantas.

\section{REFERENCES}

ARAÚJO, P. O. L. C.; GONÇALVES, F. C.; RAMOS, J. D.; CHALFUN, N. N. J.; CARVALHO, G. J. Crescimento e percentual de emergência de plântulas de citrumeleiro 'swingle' em função dos substratos e das doses de corretivo à base de Lithothamnium, após cem dias de semeadura. Ciência e Agrotecnologia, Lavras, v. 31, n. 4, p. 982-988, 2007.

ARRUDA, F. P.; BELTRÃO, N. E. M.; ANDRADE, A. P.; PEREIRA, W. E.; SEVERINO, L. S. Cultivo de pinhão manso (Jatropha curcas) como alternativa para o semi-árido nordestino. Revista de Oleaginosas e Fibrosas, Campina Grande, v. 8, n. 1, p. 789-799, 2004.

CAMARGO, R.; PIRES, S. C.; MALDONADO, A. C.; CARVALHO, H. P.; COSTA, T. R. Avaliação de substratos para a produção de mudas de pinhão-manso em sacolas plásticas. Revista Trópica: Ciências Agrárias e Biológicas, Chapadinha, v. 5, n. 1, p. 31-38, 2011.

CARNEIRO, J. G. A. Produção e controle de qualidade de mudas florestais. $1^{\text {a }}$ Ed. Curitiba: UFPR/FUPEF, 1995. $451 \mathrm{p}$.

COROMOTO, A.; CAMARGO, R. Produção de mudas de pinhão manso (Jatropha curcas L,) em diferentes substratos e tamanhos de embalagens. Revista Agropecuária Técnica, Areia, v. 31, n. 2, p. 119-125, 2010.

CRUZ, M. C. M.; HAFLE, O. M.; RAMOS, J. D.; RAMOS, P. S. Desenvolvimento do porta-enxerto de tangerineira 'cleópatra'. Revista Brasileira de Fruticultura, Jaboticabal, v. 30, n. 2, p. 471-475, 2008.

DANIEL, O.; VITORINO, A. C. T.; ALOVISI, A. A.; MAZZOCHIN, L.; TOKURA, A. M.; PINHEIRO, E. R.;SOUZA, E. F. Aplicação de fósforo em mudas de Acacia mangium Willd. Revista Árvore, Viçosa, v. 21, n. 2, p. 163-168, 1997.

DURÃES, F.O.; LAVIOLA, B. Pinhão Manso: Matéria-prima potencial para produção de biodiesel no Brasil, In: CONGRESSO BRASILEIRO DE PESQUISA EM PINHÃO MANSO. 1., 2009. Anais... Brasília: Embrapa Agroenergia, 2009. CD-Rom 
EPSTEIN, E.; BLOOM. A. Nutrição Mineral de Plantas: Princípios e Perspectivas. 2.ed. Londrina: Editora Planta, 2004. 403 p.

HAFLE, O. M.; SANTOS, V. A.; RAMOS, J. D.; CRUZ, M. C. M.; MELO, P. C. Produção de mudas de mamoeiro utilizando Bokashi e lithothamnium. Revista Brasileira de Fruticultura, Jaboticabal, v. 31, n. 1, p. 245-251, 2009.

HORSCHUTZI, A.C.O.; TEIXEIRA, M.B.I.; ALVES, J.M.I.; SILVA, F.G.I. \& SILVA, N.F. Crescimento e produtividade do pinhão-manso em função do espaçamento e irrigação. Revista Brasileira de Engenharia Agrícola e Ambiental, Campina Grande, v. 16, n. 10, p. 1093-1099, 2012. http://dx.doi.org/10.1590/S141543662012001000009

KÄMPF, A. N. Seleção de materiais para uso como substrato. In: KÄMPF, A. N.; FERMINO, M. H., ed., Substratos para plantas: a base da produção vegetal em recipientes. Porto Alegre: Genesis, 2000. p. 209215.

LIMA, R. L. S.; SOARES, L. S.; SILVA, M. I. L.; JERÔNIMO, J. F.; VALE, L. S.; BELTRÃO, N. E. M. Substratos para produção de mudas de mamona compostos por misturas de cinco fontes de matéria orgânica. Ciência e Agrotecnologia, Lavras, v. 30, n. 3, p. 474-479, 2006.

LIMA, R. L. S.; SEVERINO, L. S.; PEREIRA, W. E.; LUCENA, A. M. A.; GHREYI, H. R.; ARRIEL, N. H. C. Comprimento das estacas e parte do ramo para formação de mudas de pinhão-manso. Revista Brasileira de Enhenharia agrícola e Ambiental, Campina Grande, v. 14, n. 11, p. 1234-1239, 2009.

LOPES, A. S. Micronutrientes - Filosofias de aplicação e eficiência agronômica. São Paulo: ANDA, 1999. $72 \mathrm{p}$.

MELO, P. C.; FURTINI NETO, A. E. Avaliação do Lithothamnium como corretivo da acidez do solo e fonte de nutrientes para o feijoeiro. Ciência e Agrotecnologia, Lavras, v. 27, n. 3, p. 508-519, 2003.

MENDONÇA, V.; RAMOS, J. D.; ARAÚJO NETO, S. E.; P. I. O, R.; GONTIJO, T. C. A.; JUNQUEIRA, K. P. Substratos e quebra de dormência na formação do porta-enxerto de gravioleira cv, RBR. Revista Ceres, v. 49, n. 286, p. 657-668, 2002.

PAULINO, J.; FOLEGATTI M.V.; FLUMIGNAN D.L.; ZOLIN, C.A.; BARBOSA JÚNIOR. C.R.A. \& PIEDADE, S.M.S. Crescimento e qualidade de mudas de pinhão-manso produzidas em ambiente protegido. Revista Brasileira de Engenharia Agrícola e Ambiental, Jaboticabal, v. 15, n. 1, p. 37-46, 2011.

SEVERINO, L. S.; CARDOSO, G. D.; VALE, L. S.; SANTOS, J. W. Método para determinação da área foliar da mamoneira. Revista Brasileira de Oleaginosas e Fibrosas, Campina Grande, v. 8, n. 1, p. 753-762, 2004.

SEVERINO, L. V.; VALE, L. S.; BELTRÃO, N. E. A simple method for measurement of Jatropha curcas leaf area. Revista Brasileira de Oleaginosas e Fibrosas, Campina Grande, v. 11, n. 1, p. 9-14, 2007.

SILVEIRA, E. B.; RODRIGUES, V. J. L. B.; GOMES, A. M. A.; MARIANO, R. L. R.; MESQUITA, J. C. P. Pó de coco como substrato para produção de mudas de tomateiro. Horticultura Brasileira, Brasília, v. 20, n. 2, p. 211-216, 2002. http://dx.doi.org/10.1590/S0102-05362002000200019

WILSON, G. C. S. Use of vermiculite as a growth medium for tomatoes. Acta Horticulturae, Barcelona, v. 150, n. 1, p. 283-288, 1983. 